\title{
North Atlantic abrupt climatic events of the last glacial period recorded in Ukrainian loess deposits
}

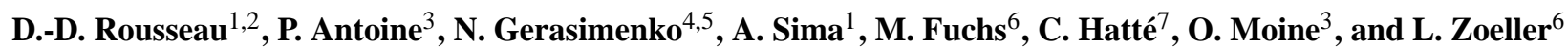 \\ ${ }^{1}$ Laboratoire de Météorologie Dynamique, UMR INSU-CNRS 8539, and CERES-ERTI, Ecole Normale Supérieure, \\ 24 rue Lhomond, 75231 Paris cedex 5, France \\ ${ }^{2}$ Lamont-Doherty Earth Observatory of Columbia University, Palisades, NY 10964, USA \\ ${ }^{3}$ Laboratoire de Géographie physique, UMR 8591 CNRS-Université Paris I Panthéon-Sorbonne, 1 place Aristide Briand, \\ 92195 Meudon cedex, France \\ ${ }^{4}$ Institute of Geography of National Academy of Sciences of Ukraine, Volodymyrska 44, Kyiv 01034, Ukraine \\ ${ }^{5}$ Earth Sciences and Geomorphology Department, Taras Shevchenko National University of Kyiv, Glushkova 2, Kyiv, \\ DSP 680, Ukraine \\ ${ }^{6}$ Chair of Geomorphology, University of Bayreuth, 95440 Bayreuth, Germany \\ ${ }^{7}$ Laboratoire des Sciences du Climat et de l'Environnement, UMR CEA-CNRS-UVSQ 8212, Domaine du CNRS, 91198 \\ Gif-sur-Yvette, France
}

Received: 5 June 2010 - Published in Clim. Past Discuss.: 1 October 2010

Revised: 30 January 2011 - Accepted: 7 February 2011 - Published: 8 March 2011

\begin{abstract}
Loess deposits are widely distributed in the Northern Hemisphere, where they have recorded not only the glacial-interglacial cycles, but also millennial-timescale changes resembling those in marine and ice cores. Such abrupt variations are clearly marked in western European series, but have not yet been evidenced in the East of the continent. Here we present results of the high-resolution investigation of a Weichselian Upper Pleniglacial loess sequence ( $\sim 38-15 \mathrm{ka})$ from Stayky, Ukraine. The stratigraphy shows an alternation of loess horizons and embryonic soils, similar to sequences from western Europe. Similarities are also found between variations of a grain-size index (ratio between coarse and fine material fractions) in Stayky and in western European profiles. Based on these similarities and in agreement with the luminescence dates, the embryonic soils are associated with the Greenland interstadials (GIS) 7 to 2, and the Vytachiv paleosol at the base of the sequence, with GIS 8. Pollen analysis indicates a wetter climate for these interstadials, allowing the development of arboreal vegetation, than for the stadials, which are marked by loess formation. The grain-size index reaches the highest values for intervals correlated with the Heinrich events 3 and 2. Thus, it appears that the North Atlantic abrupt climate changes have extended their influence and modulated the loess sedimentation at least as far as eastern Europe. This result is supported by recent
\end{abstract}

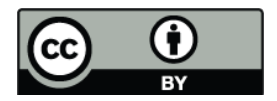

Correspondence to: D.-D. Rousseau (denis.rousseau@1md.ens.fr) climate modeling experiments and recommends the Stayky sequence as a reference for further comparisons between profiles along the Eurasian loess belt centered at $50^{\circ} \mathrm{N}$.

\section{Introduction}

European loess deposits have been investigated for many decades, and several synthetic studies have evidenced common stratigraphic features: specific units, markers, horizon succession (Kukla, 1977; Lautridou et al., 1983; Frechen et al., 2003; Rousseau et al., 2007; Zoeller, 2010). However, only a few studies have focused on the climate signature in these eolian sediments. Reanalyzing the main European loess sequences, Kukla (1977) has shown that they have preserved a variety of indications of environmental changes associated with the large-scale climatic variations revealed by the marine $\delta^{18} \mathrm{O}$ records. A further comparison with Chinese and North American synthetic loess series (Smiley et al., 1991) has even better demonstrated the potential of investigating loess sequences for reconstructing past environmental changes.

In western Europe, most of the loess deposits are located along the particular eolian corridor centered at approximately $50^{\circ} \mathrm{N}$. Since the beginning of the $90 \mathrm{~s}$, several key western European loess sequences have been investigated at high resolution along a latitudinal transect through this corridor. A refined stratigraphy has been established for the western

Published by Copernicus Publications on behalf of the European Geosciences Union. 

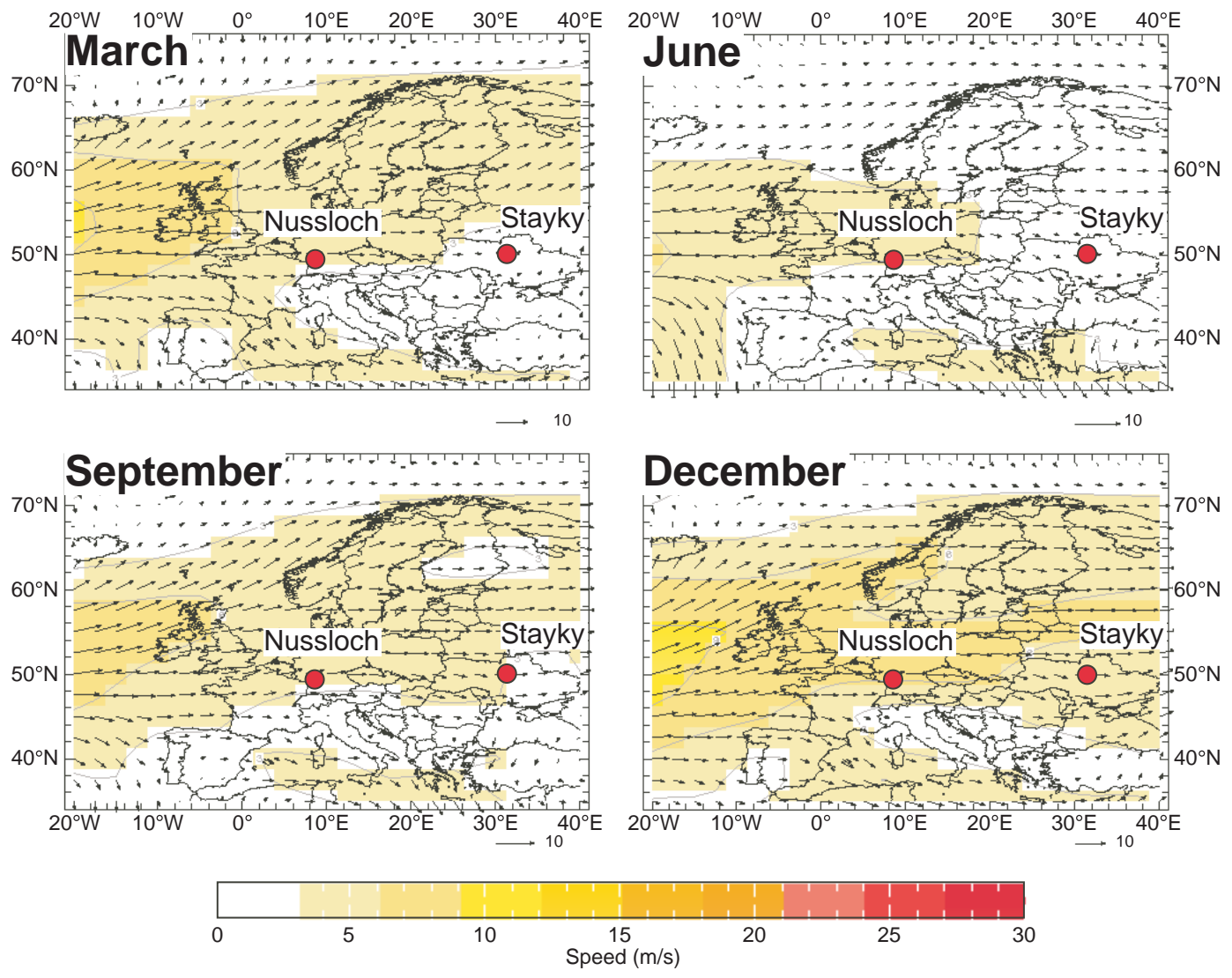

Fig. 1. Impact of Atlantic climate conditions over Europe. Modern monthly average wind speed, in $\mathrm{m} \mathrm{s}^{-1}$, at $850 \mathrm{Hpa}$ pressure level for March, June, September and December over Europe. Wind vectors plotted over shading and contours at $3 \mathrm{~m} \mathrm{~s}^{-1}$ interval. Nussloch and Stayky are two sequences cited in the text. Data source: NCEP reanalysis monthly wind components on a $2.5 \times 2.5^{\circ}$ long/lat grid for the interval 1971-2000.

European loess-paleosol series, based on data from sites as Achenheim, (Rousseau et al., 1998a, b), Saint-Pierre-lèsElbeuf, France (Antoine et al., 1999), and Nussloch, Germany (Antoine et al., 2001, 2009; Hatté et al., 1998, 2001; Lang et al., 2003; Rousseau et al., 2002, 2007). The highresolution record from Nussloch, particularly detailed for the Weichselian Upper Pleniglacial ( 38-17 ka), has become a reference for western European stratigraphy for this time interval. Close correlations have been proposed with the rapid environmental changes identified in both North Atlantic and Greenland cores, showing the intimate link between the climatic variations in western Europe and in the North Atlantic area (Rousseau et al., 2002, 2007). While the influence of the North Atlantic conditions (Fig. 1) over Europe is demonstrated in the present climate (Wallén, 1970), our aim is to investigate the eastward extent of this influence during the last glacial interval. We focus on the Weichselian Upper Pleniglacial interval, which is the main period of dust deposition during the Last Glacial (Antoine et al., 1999; Frechen et al., 2003; Rousseau et al., 1998b), and compare loess stratigraphic sequences from western and eastern Europe.
The sequence we use here as a reference for eastern Europe comes from Stayky, Ukraine, towards the eastern boundary of the European loess corridor (Fig. 2). The location was chosen based on information gathered during field trips to various loess sites in the vicinity of Kyiv (Gerasimenko and Rousseau, 2008). In order to insure a meaningful comparison between loess profiles, we have followed an investigation protocol (Sect. 2) similar to that applied to western European sequences (Antoine et al., 2001). Based on the results of a multidisciplinary analysis, we propose a long-distance correlation with the key western European loess sequence from Nussloch, and thus, with the millennial timescale climate variability in the North-Atlantic area (Bond and Lotti, 1995; Johnsen et al., 2001).

\section{Materials and methods}

The investigated loess profile Stayky $\left(50^{\circ} 05.65^{\prime} \mathrm{N}\right.$, $30^{\circ} 53.92^{\prime} \mathrm{E}, 194 \mathrm{~m}$ a.s.l.) is situated ca. $50 \mathrm{~km}$ south of Kyiv, on a cliff overhanging the Dnieper River floodplain (Fig. 2). The present climate is temperate-continental. 


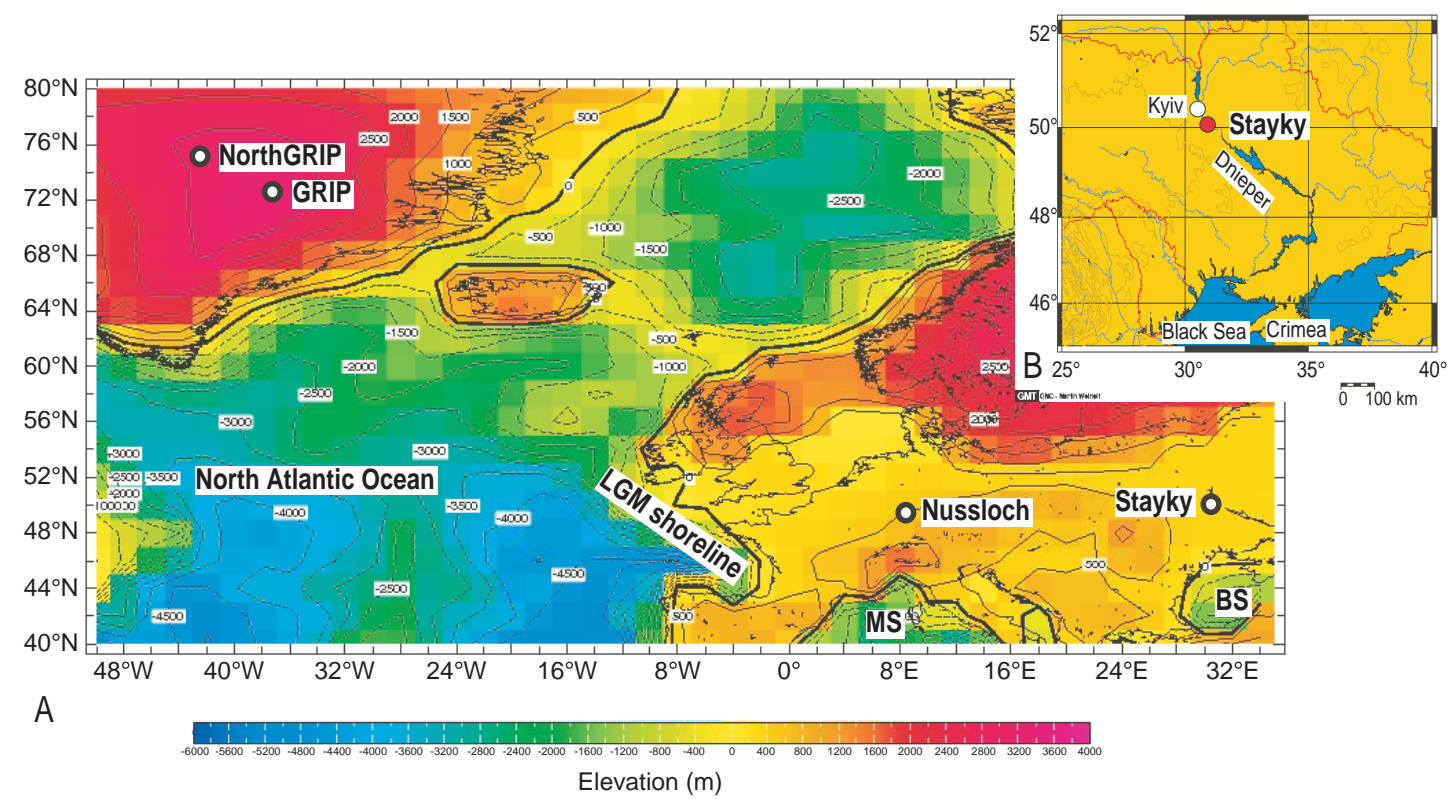

Fig. 2. Location of the studied Stayky loess sequence. (A) Map of the CLIMAP Last glacial maximum (18 K BP) topography and bathymetry showing the estimated shoreline (bold line), the emerged lands, the continental ice-sheets (represented by the $1000 \mathrm{~m}$ high line). Location of the loess series and Greenland ice-cores discussed in the text. Data from World Data Center for Paleoclimatology at $2 \times 2^{\circ}$ resolution. (B) Map of central Ukraine indicating the location of Stayky along the Dnieper River southward from Kyiv.

Mean annual precipitation is $550 \mathrm{~mm}$, with monthly means between 1.1 and $2.8 \mathrm{~mm}_{\text {day }}{ }^{-1}$. The number of days with precipitation is at least 10 per month, but most of the annual precipitation amount falls during summer. Monthly mean temperatures vary between approximately $-6^{\circ} \mathrm{C}$ in January (with a minimum of $-35^{\circ} \mathrm{C}$ ), and $20^{\circ} \mathrm{C}$ in July (with a maximum of $39^{\circ} \mathrm{C}$ ) (cf. University of East Anglia - $0.5 \times 0.5$ degree 1961-1990 Monthly Climatology). Negative temperatures are only registered between December to March. Local vegetation is represented by forest-steppe: broad-leaved forest on grey forest soils and mesophytic steppe on chernozems.

A $4 \mathrm{~m}$ wide vertical section of the loess profile was cleaned by removing the dry weathered sediment. A parallel sampling was performed on a depth of $8 \mathrm{~m}$, which is the thickness of the sediments corresponding to the Upper Pleniglacial.

The grain-size investigation of the sequence was conducted in a continuous sampling column with a resolution of $5 \mathrm{~cm}$ between 1.5 and $7 \mathrm{~m}$ depth, whereas in the upper strata, where evidence of bioturbation was present, individual samples were taken with a resolution of $10 \mathrm{~cm}$. The sediment samples were analyzed using a laser coulter. Parallel to the grain-size sampling, the low field magnetic susceptibility (MS) was measured every $10 \mathrm{~cm}$ depth in loess units and every $5 \mathrm{~cm}$ in paleosols, using a portable Bartington MS2 meter. Following the methodology already used for other loess sequences (e.g., Achenheim, St. Pierre les Elbeuf, Nussloch, Surduk), each measurement was obtained by averaging 10 individual readings. These measurements were not conducted for determining the paleomagnetic properties of the sediment, but only to provide support in identifying the different stratigraphical units. Thus, except for deposits in Siberia, Alaska and New Zealand, the paleosols are generally characterized by higher values than the eolian layers (Kukla et al., 1988). To establish a chronostratigraphy for the Stayky loess profile, based on the loess - pedocomplex alternations, the sequence was correlated to the general Ukrainian Quaternary loess stratigraphy (Gerasimenko, 2006; Veklitch et al., $1984 a$, b). In order to obtain additional chronostratigraphic information, 4 sediment samples were taken for numerical dating, using infrared stimulated luminescence (IRSL) dating techniques. The samples were taken in opaque copper cylinders, and the fine grain $(4-11 \mu \mathrm{m})$ polymineral fraction was extracted to determine the equivalent dose (De), applying a multiple aliquot additive (MAAD) and regenerative (MAR) dose protocol (Mauz et al., 2002). Dose rates were calculated using $\mathrm{U}$, Th and $\mathrm{K}$ concentrations obtained by high- resolution low level $\gamma$-spectrometry, taking into account a water content (ratio of wet to dry sample weight) of $1.15 \pm 0.05$ and a minor depth-dependent contribution of cosmic radiation. Alpha efficiency values (a-values) were determined for the samples BT 31 and BT 33, obtaining an a-value of $0.08 \pm 0.01$ for both of the samples. This a-value was also used for the remaining samples. To account for short-term anomalous fading, the aliquots were stored after laboratory irradiation for a minimum of 4 weeks at room temperature or a minimum of 1 week at $70^{\circ} \mathrm{C}$ (Berger, 1987). 


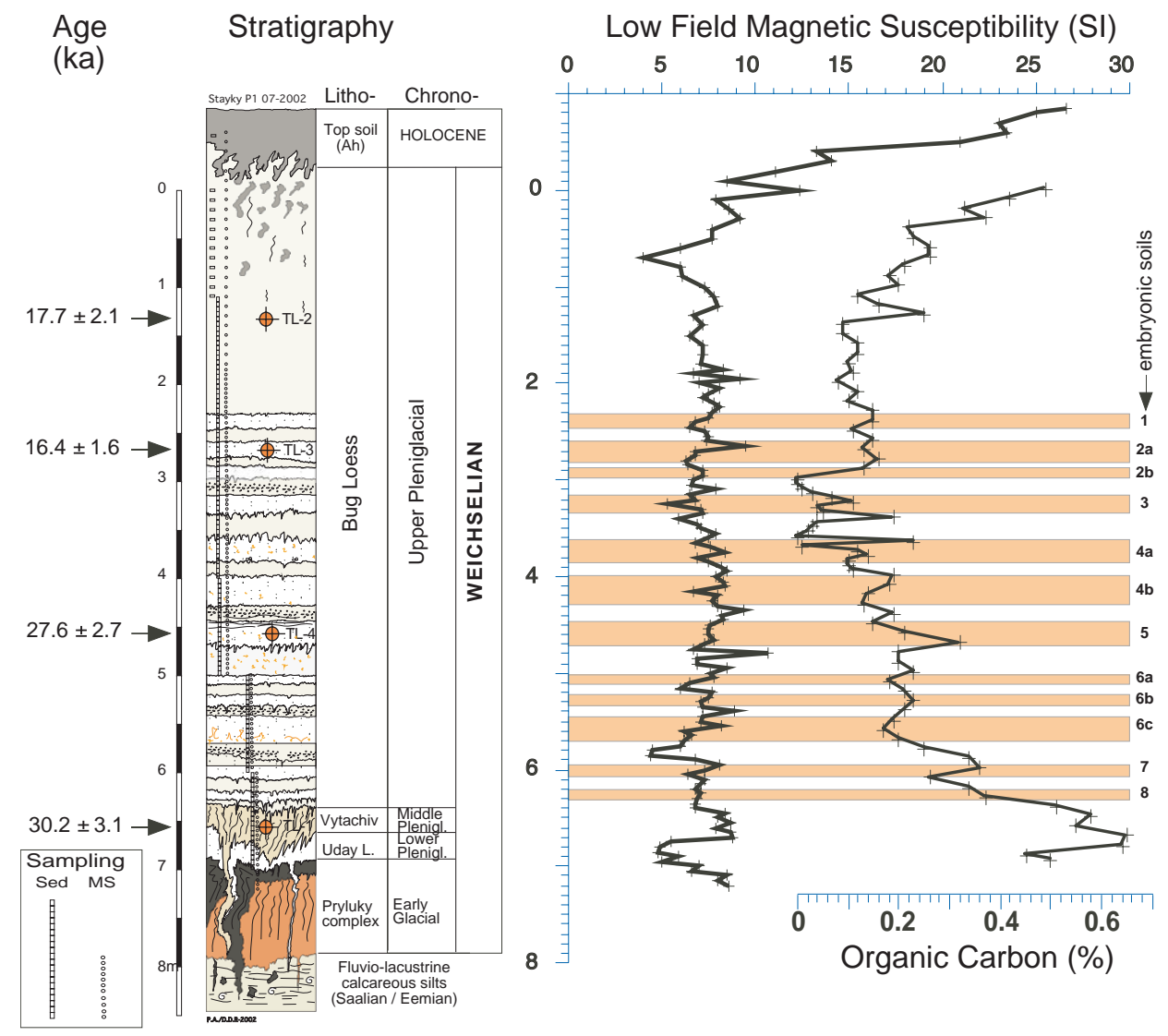

Fig. 3. Stayky loess sequence: stratigraphy and IRSL dates, low field magnetic susceptibility measured on the section, and organic carbon records, with the count of the embryonic soils (ES).

The multiple aliquot additive dose (MAAD) protocol is a well-established protocol in the field of loess dating, as it prevents the risk of sensitivity change (Wintle, 1997). Its disadvantage is, however, relatively large De error bars due to the aliquot-to-aliquot scatter and the extrapolation of the growth curve. De error bars obtained from the regeneration method (MAR) are normally much smaller, but are only acceptable if no significant sensitivity change can be seen from the additive and regenerated growth curves. In this study, when the MAAD and MAR ages differed significantly, the more reliable MAAD ages were used. In cases where the obtained ages from both of the protocols were the same within errors, the MAR ages were used due to their smaller errors (Table 1).

Pollen samples were taken at the same levels as for the grain size investigation, and 22 selected samples have been analyzed (Sect. 3.5). Pollen processing included $10 \mathrm{~min}$. boiling in $\mathrm{HCl}, \mathrm{Na}_{4} \mathrm{P}_{2} \mathrm{O}_{7}, \mathrm{HCl}$ and $\mathrm{KOH}$ (with the consequent decanting), treatment with cold $\mathrm{HF}$ and centrifuging in heavy liquid $\left(\mathrm{CdI}_{2}+\mathrm{KI}\right)$ of specific gravity 2.0 and 2.2.

\section{The stayky last glacial sequence}

The Weichselian Upper Pleniglacial stratigraphy has been intensively studied in the central Ukraine since the basic investigations by Veklitch and co-workers (Gerasimenko, 2006; Veklitch et al., 1984a, b). Therefore, the different stratigraphic units are well defined. In the previously studied Stayky loess section, which represents the standard profile of the Ukrainian loess stratigraphy (Gerasimenko and Rousseau, 2008; Veklitch et al., 1984a, b), the Upper Pleniglacial loess is about $3 \mathrm{~m}$ thick, and has been related to one homogenous palynological complex. At the new site, located $6 \mathrm{~km}$ further north, the Bug loess is twice as thick, which allows a much more detailed investigation of the loess sequence.

\subsection{Stratigraphy}

The base of the Stayky Last Glacial series (Fig. 3) overlies a fluviolacustrine calcareous silt and hydromorphic soil assigned to the Saalian-Eemian interval, i.e. equivalent to marine isotope stages (MIS) 6 and 5e. The Last Glacial starts with the Pryluky soil complex, consisting of a thick dark grey-brown mollic horizon (Chernozem) overlain by a 
Table 1. IRSL dating results.

\begin{tabular}{|c|c|c|c|c|c|c|c|}
\hline $\begin{array}{l}\text { Lab. } \\
\text { sample }\end{array}$ & $\begin{array}{l}\text { Field sample/ } \\
\text { Depth }\end{array}$ & $\begin{array}{c}\mathrm{U} \\
(\mathrm{ppm})\end{array}$ & $\begin{array}{c}\mathrm{Th} \\
(\mathrm{ppm})\end{array}$ & $\begin{array}{l}\mathrm{K} \\
(\%)\end{array}$ & $\begin{array}{c}\text { Dose } \\
\text { rate } \\
(\mathrm{Gy} / \mathrm{ka})\end{array}$ & $\begin{array}{c}\text { Equivalent } \\
\text { dose De } \\
(\mathrm{Gy} \pm 1 \mathrm{~s}) \\
\mathrm{r}=\text { regen }\end{array}$ & $\begin{array}{c}\text { Age } \\
(\mathrm{ka} \pm 1 \mathrm{~s}) \\
\mathrm{a}=\text { additive }\end{array}$ \\
\hline BT 32 & TL-2 $150 \mathrm{~cm}$ & 2.43 & 8.38 & 1.63 & 3.35 & $\begin{array}{l}58.9 \pm 5.7 \\
50.1 \pm 2.1\end{array}$ & $\begin{array}{c}\text { a } \mathbf{1 7 . 6} \pm \mathbf{2 . 0} \\
\text { r } 15.0 \pm 1.1\end{array}$ \\
\hline BT 33 & TL-3 $270 \mathrm{~cm}$ & 2.23 & 8.00 & 1.76 & 3.30 & $\begin{array}{l}50.6 \pm 5.1 \\
54.0 \pm 2.7\end{array}$ & $\begin{array}{l}\text { a } 15.3 \pm 1.8 \\
\text { r } \mathbf{1 6 . 4} \pm \mathbf{1 . 2}\end{array}$ \\
\hline BT 34 & TL-4 $450 \mathrm{~cm}$ & 2.43 & 8.63 & 1.92 & 3.60 & $99.1 \pm 4.2$ & a $27.6 \pm 2.0$ \\
\hline BT 31 & TL-1 $650 \mathrm{~cm}$ & 2.45 & 10.07 & 1.79 & 3.62 & $\begin{array}{c}106 \pm 18 \\
109 \pm 5.2\end{array}$ & $\begin{array}{l}\text { a } 29.3 \pm 5.3 \\
\text { r } \mathbf{3 0 . 1} \pm \mathbf{2 . 3}\end{array}$ \\
\hline
\end{tabular}

Note: Water content (ratio of moist vs. dry weight) was taken as $1.15 \pm 0.05$ for all samples. The a-value was measured for samples BT 32 and BT 33 as $0.08 \pm 0.01$, and this value was used in calculations for the other two samples as well. U-, Th- and K-concentrations are based on low-level $\gamma$-spectrometry.

truncated brownish cambisol horizon. Both horizons are dissected by deep root tracks and some frost wedges filled with grey silt. The boundary between them is very irregular. A first loess layer, about $20 \mathrm{~cm}$ thick, marks the beginning of the Pleniglacial. It is allocated to MIS 4, and, according to the Ukrainian stratigraphical nomenclature, to the Uday loess unit. The brown soil horizon overlying the Uday loess is allocated in the Ukrainian nomenclature to the Vytachiv unit. This unit is only 20 to $70 \mathrm{~cm}$ thick at Stayky, but much thicker (up to $2.5 \mathrm{~m}$ ) in other Ukrainian sections (Gerasimenko and Rousseau, 2008). For exemple, at Vyazivok (Rousseau et al., 2001), it is represented by a soil complex composed of at least two distinct soil horizons, and is mainly allocated to the 55-30 ka interval (roughly, the MIS 3).

The $6.5 \mathrm{~m}$ thick sediments on top of the Vytachiv layer show typical calcareous loess deposits. They are allocated to the Bug loess, the thickest loess unit of the Ukrainian Upper Pleistocene stratigraphy, as observed in other neighboring sequences. The Bug loess can be divided into two parts as described in the Kyiv area (Gerasimenko and Rousseau, 2008). The lower part, $4 \mathrm{~m}$ thick, consists of calcareous loess units alternating with weakly developed pedological horizons (embryonic, or incipient soils), identified by a more brownish color and fine root track networks. Two of the pedological horizons, the unit between horizons 5 and $6 \mathrm{a}$, and the lower part of the unit $6 \mathrm{c}$, are characterized by iron oxide patches and tracks within a grayish matrix. They correspond to weakly developed tundra gley layers, indicating short periods of water logging. This interpretation is supported by both pollen and mollusk investigations in neighboring sequences (Gerasimenko and Rousseau, 2008). All the other pedological horizons are only incipient soils. This stratigraphical succession is similar to the gley-loess doublets identified in the upper (thickest) part of the Nussloch sequence, in the Rhine Valley (Antoine et al., 2001, 2009). The upper part of the Bug loess, $2.5 \mathrm{~m}$ thick, consists of rather homogenous calcareous loess. Bioturbations are visible in the upper $1 \mathrm{~m}$, related to the formation of the topsoil (unit 0) which is a chernozem horizon partly eroded at the top, corresponding to the Late Holocene (Gerasimenko, unpublished data).

\subsection{IRSL ages}

The additive and regenerative ages (MAAD and MAR protocol, respectively) yielded by the 4 samples analyzed for dating are consistent within error bars (Table 1). The validated ages are marked in bold. In the case of BT 31 and BT 33 we use the regenerative ages because of smaller errors. With BT 32 we use the additive age because of a possible sensitivity change.

The validated IRSL ages support the main features of the defined stratigraphy (Fig. 3). The sediment age obtained for the Vytachiv soil complex indicates that this has formed during MIS 3, supporting the previously proposed stratigraphic correlation with central European sequences (Rousseau et al., 2001). This soil can also be correlated with the arctic brown soil named Lohner Boden (Schirmer, 2000) and described at Nussloch as a gelic cambisol (Antoine et al., 2001). Furthermore, the three IRSL ages obtained for the Bug loess place it as contemporaneous of the thick loess unit observed in western European deposits, as already suggested by a comparison with the Dolní Vestonice loess sequence in the Czech Republic (Rousseau et al., 2001).

\subsection{Magnetic susceptibility}

The magnetic susceptibility (Fig. 3) shows high values in the Vytachiv soil and in the chernozem at the top of the sequence. This is a common feature of European loess sequences, due to weathering and biological activity in soil horizons. In contrast, the values are low in the Uday loess and exhibit no particular variation, considering the measurement error. The 5 to $20 \mathrm{~cm}$ thick incipient horizons present no specific variations of the magnetic susceptibility as well. 


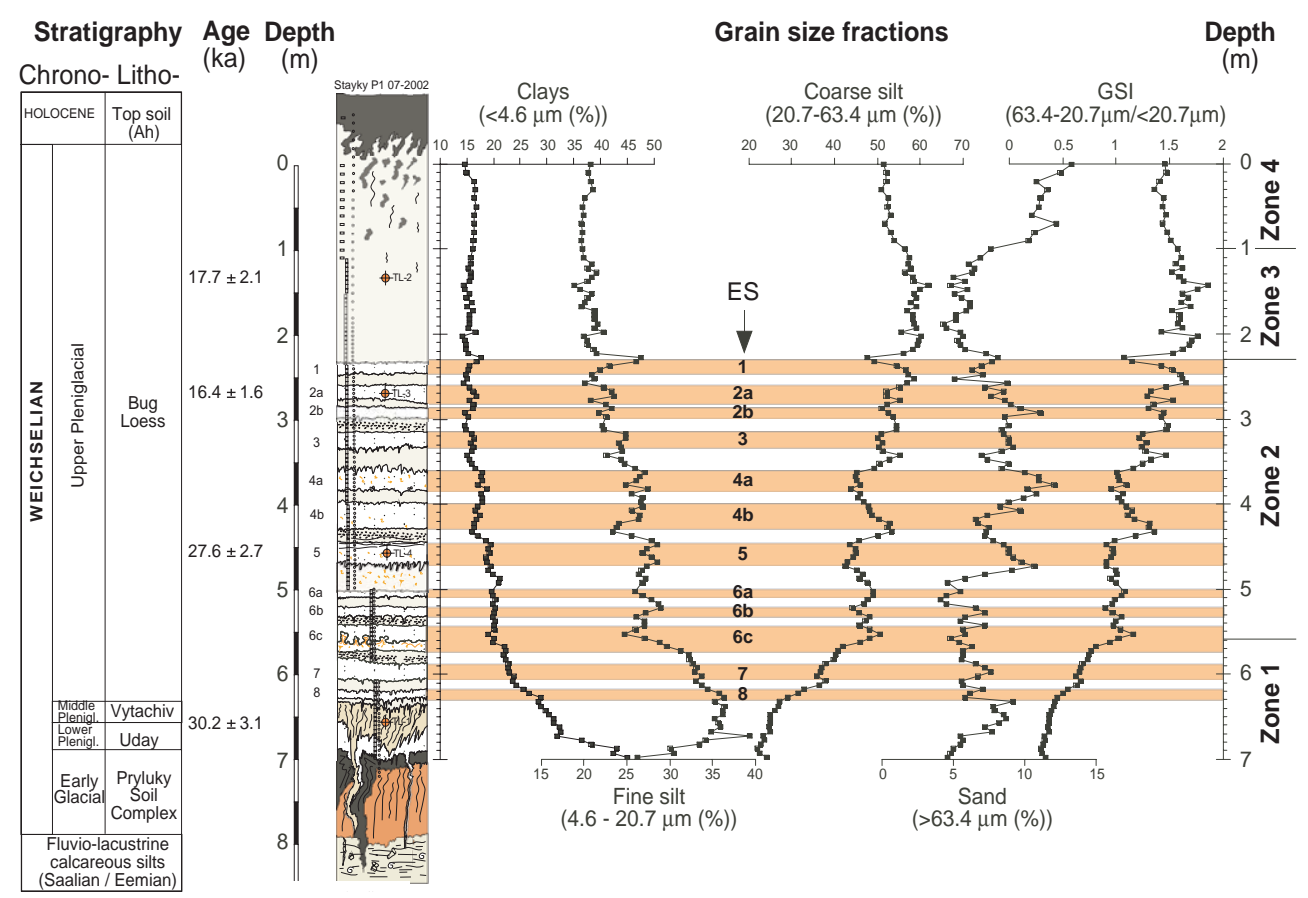

Fig. 4. Grain size variations in the Stayky loess sequence. Plots of the four identified size fractions (clay, fine silt, coarse silt, sand) and of the grain size index (GSI), defined as the ratio between coarse and fine material fractions.

They are only marked by slight increases in the organic carbon values (Fig. 3). This suggests that they represent relatively short intervals of decrease, probably of just a few hundred years or even a stop of the eolian deposition. These intervals were also characterized by enhanced humidity, as indicated by loess weathering (which requires increased moisture to initiate), and by a development of arboreal vegetation shown by the pollen analysis (Sect. 3.5).

\subsection{Grain size analysis}

With respect to grain size, the Upper Pleniglacial section of the Stayky loess profile can be divided into four consecutive classes: clays $(<4.6 \mu \mathrm{m})$, fine silt $(4.6-20.7 \mu \mathrm{m})$, coarse silt $(20.7-63.4 \mu \mathrm{m})$ and fine sand $(63.4-153.8 \mu \mathrm{m})$, their relative contribution varying with depth (i.e., through time) (Fig. 4). As no evidence of water transport has been noticed in the field, these variations can be entirely attributed to changes in the eolian dust cycle (emission, transport, deposition).

Four main zones can be distinguished (Fig. 4), which can be interpreted as corresponding to different climate regimes.

1. Above the Priluky paleosol and up to $5.6 \mathrm{~m}$ depth the clay content regularly decreases, from ca. $45 \%$ to ca. $15 \%$, while the coarse silt percentage doubles (from ca. $20 \%$ to $40 \%$ ). The fine silt content first increases to ca. $37 \%$ toward the top of the Vytachiv soil, then returns to values of ca. $25 \%$, similar to those at the base of this part of the sequence. The sand fraction remains low and does not show any particular variations. Considering all the material as windblown, the increasing fraction of coarser material upwards might be interpreted as reflecting a gradual intensification of the wind dynamics, with a possible increase in the frequency of strong wind episodes. We note that, in general, a shift to coarser grain material could also be due to a change in the source material or location, or to less strong winds in the source regions, decreasing the kinetic energy picking up and breaking apart the materials, and thus increasing the size of the entrained material.

2. Between $5.6 \mathrm{~m}$ and $2.2 \mathrm{~m}$ depth, the fine silt and clay fractions generally remain at low values, and show two stable states: the first between 5.6 and $3.6 \mathrm{~m}$ (at ca. $27 \%$ and ca. 20\% respectively), and the second between 3.6 and $2.2 \mathrm{~m}$ (at ca. $15 \%$ and ca. $23 \%$ respectively). The coarse silt content shows a cyclic pattern on an increasing trend. The sand fraction reproduces this pattern inversely, but at much lower values. This increase in coarse silt may be, once more, interpreted as being related to a strengthening in the wind regime, but with a more cyclic pattern than in the previous zone.

3. From $2.2 \mathrm{~m}$ up to $1 \mathrm{~m}$ depth, the proportions of the different grain size classes remain relatively stable, with the coarse and fine silts predominating, while the clays and the sands only are at about $15 \%$ and 5\% respectively. 
(a) Greenland Interstadial

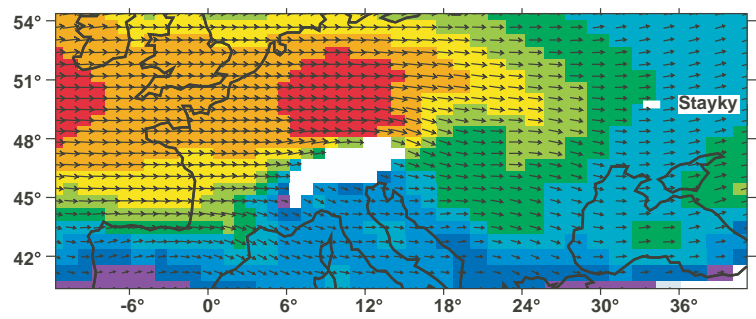

(b) Greenland Stadial

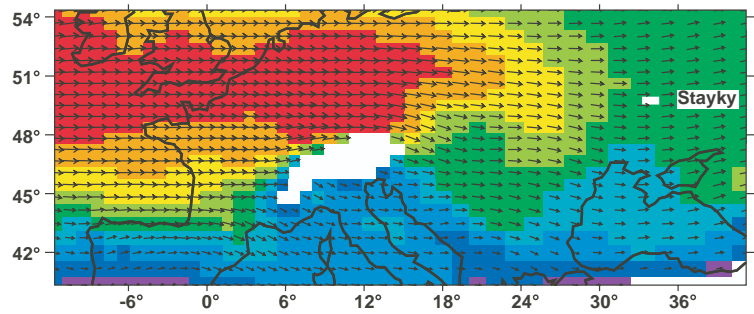

(c) Heinrich event

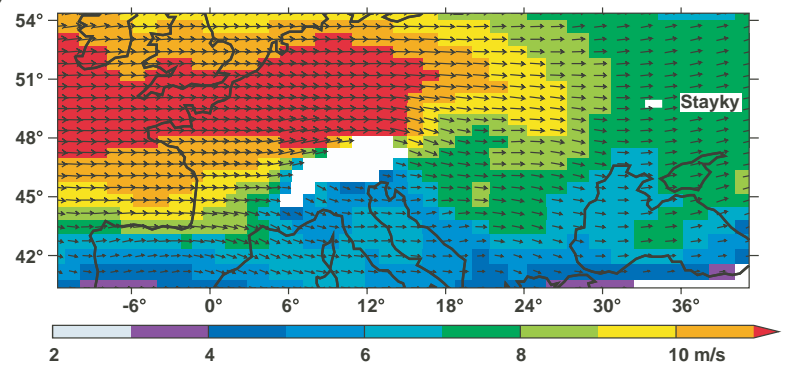

Fig. 5. Average wind field at $850 \mathrm{hPa}$ in Europe at temperate latitudes for three simulated climate states associated with (a) a Greenland Interstadial, (b) a Greenland Stadial and a Heinrich event (c) (after Sima et al., 2009). The Stayky location is marked.

4. In the top $1 \mathrm{~m}$, the sand fraction increases at the expense of the fine and coarse silts. This might correspond to a change in the main source of material, which becomes most likely more local, from the Dnieper valley.

With respect to the four size fractions analyzed, the embryonic soils identified in the stratigraphy are generally characterized by a decrease in coarse silt and sand and an increase in the fine silt components (Fig. 4). They are also associated with an increase in organic carbon (Fig. 3).

The coarse material (coarse silts and sand) comes from sources relatively close to the site, while the fine material (clays and fine silts) has been transported from more distant areas as well (probably hundreds to a thousand $\mathrm{km}$ away from the site), via high-altitude atmospheric transport (Duce, 1995; Pye, 1995). Geochemical analyses of eolian deposits in the southern Ukraine correlated with the presence of sand units south of Stayky (Buggle et al., 2009) and have been interpreted as indicating a predominant northern wind direction. One hypothesis, first suggested by Tutkovsky (1910), is that dust has been brought by katabatic winds blowing down the Fennoscandian ice sheet, which margin, at the maximum extent, was at about $400 \mathrm{~km}$ north of Stayky (Svendsen et al., 2004). This hypothesis is questionable, because katabatic winds observed over the Antarctic ice sheet only reach between 20 and $100 \mathrm{~km}$ offshore (Adolphs and Wendler, 1995), and this ice sheet is considerably larger than the Fennoscandian was, according to reconstructions by Svendsen et al. (2004).

Recent experiments with an atmospheric general circulation model (Sima et al., 2009) have addressed the changes in dust emission induced in western Europe during the Upper Pleniglacial by the North Atlantic millennial timescale variability. They indicate predominantly western winds over all of Europe in all three simulated types of glacial climate states: Greenland stadial, interstadial and Heinrich event (Fig. 5). Furthermore, while coarse silt and sand are largely available in the braided plain of the Dnieper river, at only approximately $100 \mathrm{~m}$ east of the site, the coarse grain content in the main part of the sequence is low. Thus, easterly winds do not seem to have been the main winds transporting eolian material to the site. All these suggest that the main dust sources for the Stayky loess sediments must have been located generally west of Stayky.

In addition to predominantly western winds, the numerical simulations described in Sima et al. (2009) show temperature anomalies associated with the North-Atlantic millennial timescale changes extending from west to east over Europe (Fig. 6). Significant precipitation anomalies are also simulated for the interstadial state GIS with respect to the reference stadial state GS. If the North Atlantic events impacted the entire continent (at least at our latitudes of interest, around $50^{\circ} \mathrm{N}$ ), as also suggested by previous numerical experiments at coarser resolution (Ganopolski and Rahmstorf, 2001; Claussen et al., 2003; Jin et al., 2007), then a correlation should exist between loess sedimentation variations in western and eastern Europe. The existence of such a correlation is investigated in the following by comparing in detail the Stayky sequence, taken as a reference for eastern Europe, to the Nussloch sequence. Here, we would like to bring your attention to the fact that Nussloch is the most detailed loess sequence of western Europe, and is correlated to the North Atlantic records (Rousseau et al., 2007). The variations with time (depth) of the loess grain-size composition are mainly related to a combination of changes in the wind and precipitation regimes, from local to much larger spatial scales (Duce, 1995). These changes affect the dust cycle directly through their effect on the efficiency of dust entrainment, dust transport and deposition and indirectly by changing the distribution and characteristics of the dust source areas, including variations of the vegetation cover in the source areas. A simple way to characterize the combined effect of all these environmental changes on the loess sedimentation is to define a grain-size index (GSI) as the ratio between the coarse and the fine material fractions (Rousseau et al., 2002). Such an 
(a) GS sfc temperature (C)

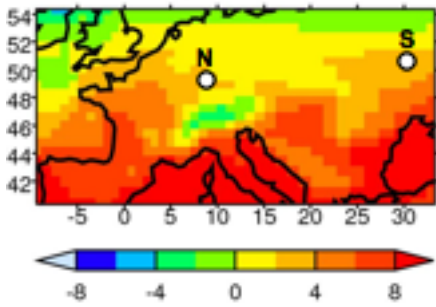

(d) GS precipitation ( $\mathrm{mm} /$ day)

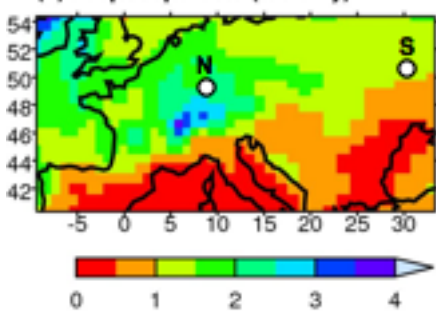

(b) HE-GS sfe temperature (C)

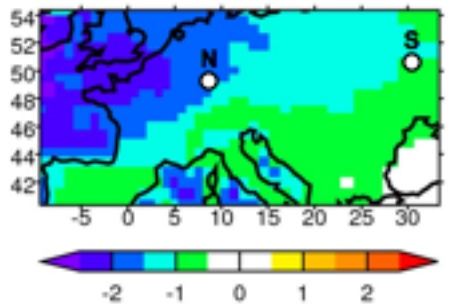

(e) HE-GS precipitation ( $\mathrm{mm} / \mathrm{day}$ )

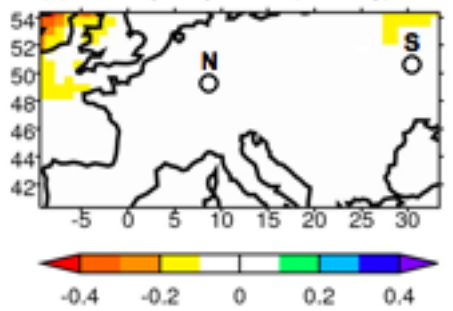

(c) GIS-GS sfe temperature (C)

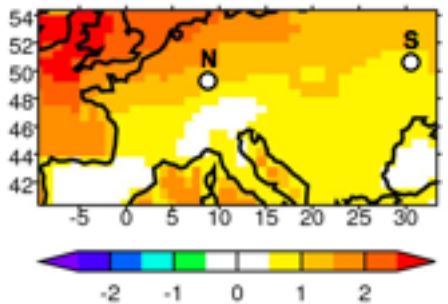

(f) GIS-GS precipitation ( $\mathrm{mm} / \mathrm{day}$ )

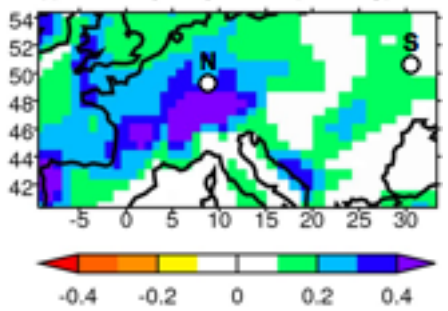

Fig. 6. Surface air temperature (a-c), and precipitation (d-f): absolute annual mean values for the reference GS state (left column) and annual mean anomalies HE-GS (middle column) and GIS-GS (right column). (modified from Sima et al., 2009). In white, areas where the differences are not significant to the $95 \%$ confidence level (Student's t-test).
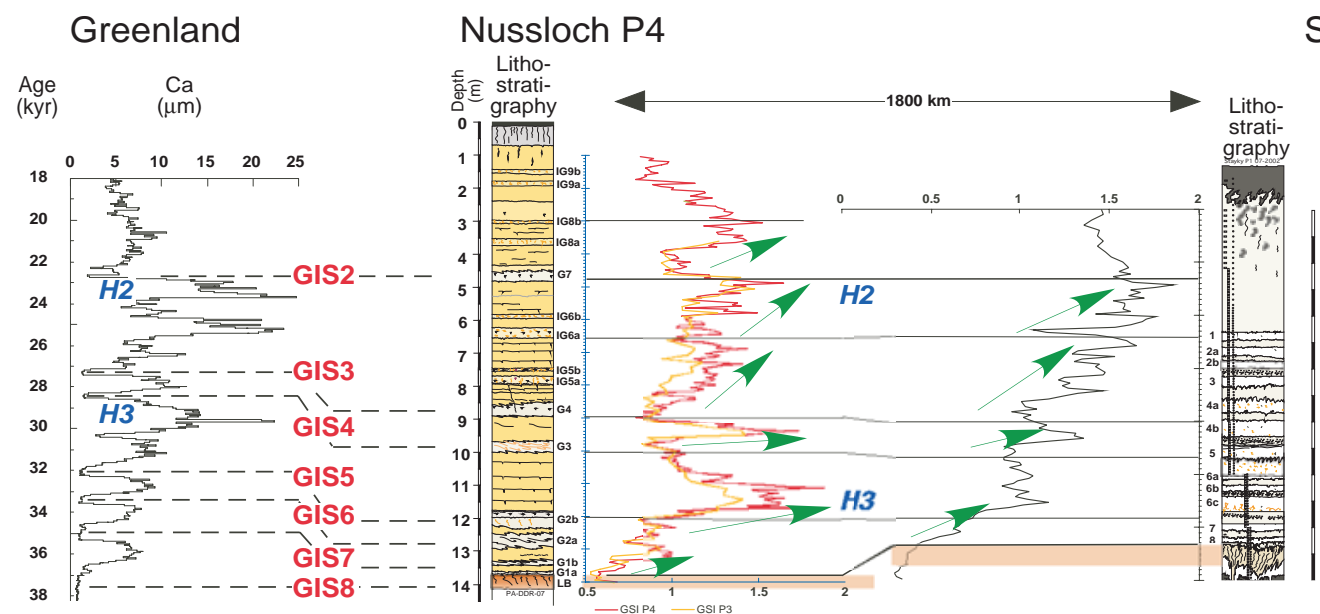

Stayky

Fig. 7. Comparison between the grain size index (GSI) records in Nussloch (P3 and P4 sequences) (after Rousseau et al., 2007) and in Stayky (this study). Identification of similar cycles (marked by the green arrows), and proposed correlation between the two continental records, supported by IRSL dates, and pollen characteristics (arboreal pollen - AP- percentages) of the embryonic soils. Correlation between the Greenland GRIP dust record (Johnsen et al., 2001) and the Nussloch record according to Rousseau et al. (2007), with GIS 8 correlated with the Nussloch Löhner Boden (LB) following Fig. 9. H3 and H2 correspond to marine Heinrich events 3 and 2 in the Greenland and European records. G1-7 and IG5-9 are the identified gleys or oxidized horizons in Nussloch.

index, calculated as the ratio $(52.6-26 \mu \mathrm{m}) /<26 \mu \mathrm{m}$ (Fig. 4), has been used along with high-resolution stratigraphy and magnetic susceptibility measurements to correlate western European sequences and to compare them with North Atlantic marine and Greenland ice core records (Antoine et al., 2009; Rousseau et al., 2002, 2007) (Fig. 7). For the Upper Pleniglacial, high GSI values characterize loess units deposited at high accumulation rates in cold, dry and windy conditions, corresponding in western Europe to the North
Atlantic cold phases: Greenland stadials and $\mathrm{H}$ events. Low GSI values are associated with soil horizons or tundra gley layers developed in a relatively warmer and moister climate, corresponding to Greenland interstadials.

The GSI in the Stayky sequence varies over a broad range of values, from ca. 0.2 in the Vytachiv paleosol at the base to a maximum of ca. 2 in the upper Bug loess (Fig. 4). The ratio of these extreme values, about 10 , is considerably higher than the ratios determined for the European sequences: between 


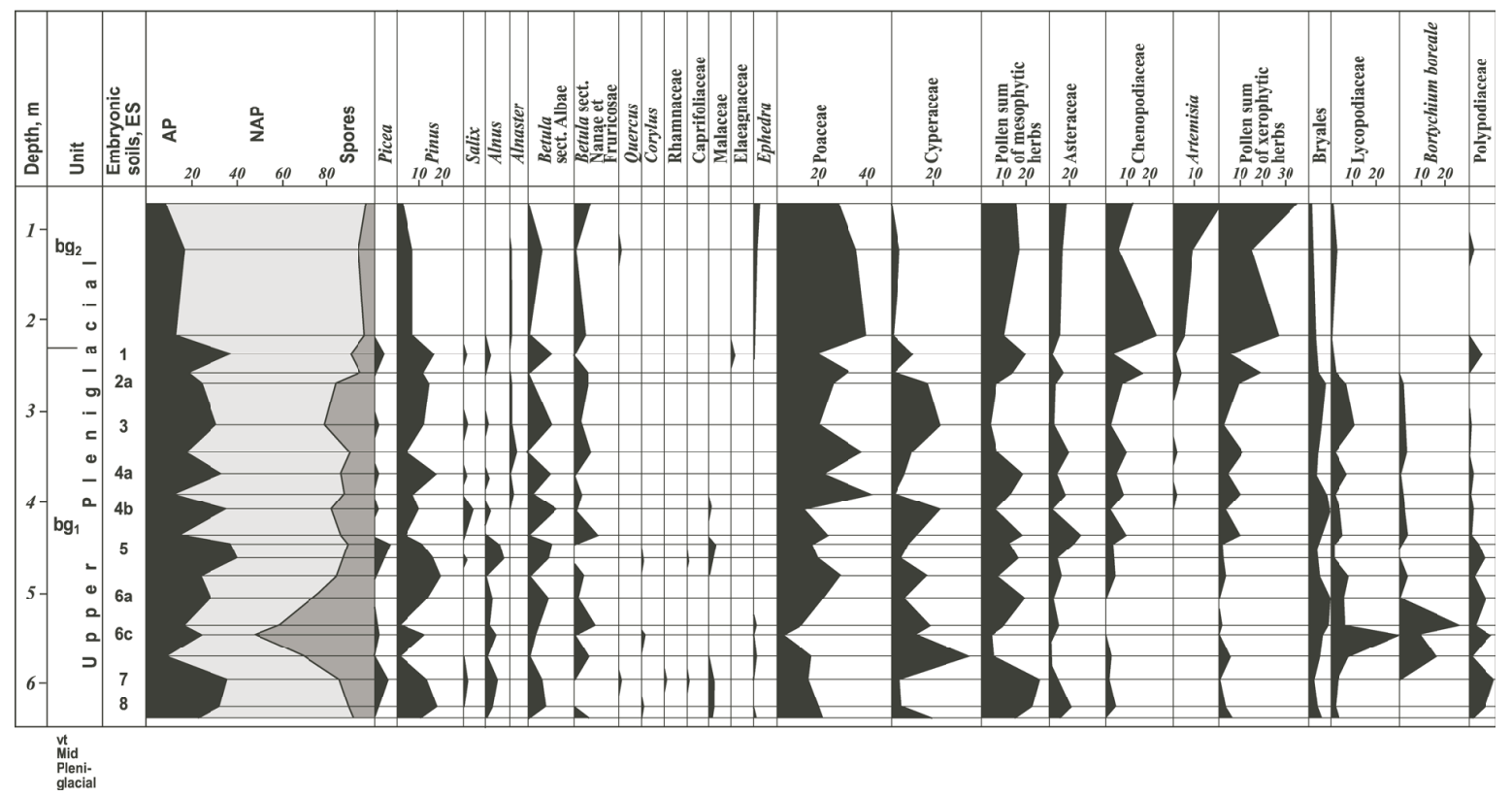

Fig. 8. Synthetic pollen diagram for the Stayky sequence.

3 and 6 for the three Nussloch (Germany) profiles, 6 for the Renancourt (northern France) profile (Antoine et al., 2009). This difference is due to the considerably smaller minimum value at Stayky, which can be attributed to a much higher clay content in the Vitachiv paleosol (ca. 35\% from the total) compared to its stratigraphic equivalent in Nussloch, the Lohner Boden (ca. 19\%). The median of the grain-size distribution is also lower in Stayky than in Nussloch, reflecting a finer grain composition.

This last observation might indicate that the particles forming the Stayky Upper Pleniglacial loess have been carried over a long distance by high altitude transport. A source area might have been the outwash plains of the Fennoscandian ice sheet, lying some hundreds of kilometers northwest of Stayky. Such a situation is similar to that of the eolian deposits from northwestern Europe, where a decrease of the grain-size median from NNW to SSE was demonstrated (Lautridou, 1985; Lautridou et al., 1983, 1986). This grain-size gradient is related to the relative position of the corresponding dust sources: the English Channel and southern North Sea basins, exposed to deflation due to sea level lowering in glacial times.

\subsection{Pollen analysis}

Pollen of broad-leaved trees is practically absent in the studied Upper Pleniglacial sequence. The climate indices we use here are the arboreal and non-arboreal pollen percentages (AP and NAP), the pollen sums of cryophytes, herbal xerophytes and mesophytes. All these indices exhibit cyclic variations superposed on a general trend (Fig. 8). The climate was generally cold, as shown by the pollen of Betula sect. Nanae et Fruticosae, Alnaster, Botrychium boreale and a few Selaginella selaginoides: pollen of shrub Betula appears in all samples, and Alnaster is always present above the $3.90 \mathrm{~m}$ level.

Concerning the humidity, a first important change can be observed at $2.30 \mathrm{~m}$ depth and divides the Bug loess in two parts. The lower part, Bug loess sub-unit $b_{1}$, between 6.35 and $2.30 \mathrm{~m}$, is characterized by rather high counts of AP (13$40 \%$ ), of spores and pollen of sedges. In the upper part, the $\mathrm{bg}_{2}$ sub-unit $(2.30-0.70 \mathrm{~m})$, the AP counts decrease and their composition becomes much poorer than in the $\mathrm{bg}_{1}$ deposits (Betula sect. Nanae et Fruticosae, Alnaster, Pinus and rarely arboreal Betula). In the NAP, pollen counts of xerophytes (Chenopodiaceae, Artemisia and few Ephedra) become considerable (15-34\%), in parallel with grasses, whereas the percentages of sedges pollen and of spores are very low. This indicates a significantly wetter climate during the early Bug interval, $\mathrm{bg}_{1}$, than during $\mathrm{bg}_{2}$.

A second important change, also concerning humidity, occurs within the $\mathrm{bg}_{1}$ sub-unit, at $3.90 \mathrm{~m}$ depth. The pollen counts of grasses are considerably lower between 6.35 and $3.90 \mathrm{~m}$ than above (4-28\% compared to $17-42 \%$ ). On the contrary, the AP and the pollen counts of mesophytic herbs are higher, and the AP diversity is larger in the $6.35-3.90 \mathrm{~m}$ interval. Pollen grains of bushes (Malaceae, Caprifoliaceae and even Corylus and Rhamnaceae) are present here (1-2\%), and pollen grains of Picea, Alnus and arboreal Betula are more frequent than in the layers above. The typical steppe (grassland) appears above the $3.90 \mathrm{~m}$ level. All these indicate wet conditions in the first part of the bg $_{1}$ loess formation, and an increase of aridity in the second part of this period. 
Another type of climate variations, more rapid and cyclic, is related to the embryonic soils (ES) observed in the $\mathrm{bg}_{1}$ sub-unit. The alternation of loess units and embryonic soils reflects variations of humidity, but also of temperature. The soils differ from the loess layers by higher counts in AP and in mesophytic herbs, by the presence of Polypodiaceae spores and by lower counts (or even absence) of cryophytic plant pollen. They represent phases of incipient pedogenesis, in a wetter - and, for some of them, also warmer - climate than during the loess accumulation. In the following, they are analyzed in detail.

The climate conditions corresponding to ES7 and ES5 (particularly to the $4.65-4.60 \mathrm{~m}$ depth interval) were warmer than for the other embryonic soils, as indicated by a richer AP composition and the absence of pollen of cryophytes. The herbal cover was mesophytic (herbs and grasses), and there was no excessive moisture in the ground at this time, as indicated by the low pollen counts of sedges. Between 5.70 and $5.00 \mathrm{~m}$, spores are over-represented. The loess layers have high spore counts of Botrychium boreale and high pollen counts of sedges and of Betula sect. Nanae et Fruticosae. This indicates a cold and wet tundra and tundra-steppe environment (with a few trees).

The embryonic soils ES6a and ES6c include spores of Bryales, Polypodiaceae and Lycopodiaceae; ES6c also includes spores of arcto-boreal species (Botrychium boreale and a few Selaginella selaginoides). They have been also formed under excessive ground moisture, in a cold climate. Still, it was less cold than during loess accumulation periods, allowing boreal forest to develop. Water-logged environments were also typical for the ES4b and ES3, as indicated by the pollen counts of sedges.

To summarize, the evolution of the vegetation cover in the studied sequence was as follows: during the formation of the first part of $\mathrm{bg}_{1}$ sub-unit (up to the $3.90 \mathrm{~m}$ level, including ES4b), boreal and arcto-boreal forest-steppe alternated with forest-tundra, whereas during the second part, arcto-boreal forest-steppe alternated with periglacial steppe. During the $\mathrm{bg}_{2}$ times, only periglacial steppe existed. In terms of climate, the Bug loess formation began in wet conditions, and has continued on an increasing aridity trend. It was generally cold, with short slightly warmer episodes associated with some of the embryonic soils.

\section{Correlation between the Stayky and Nussloch loess sequences}

Investigating loess sequences located south of Kyiv, Gerasimenko and Rousseau (2008) concluded that, for the Pleniglacial, these sequences show a pattern similar to the Nussloch statigraphy: a succession of stratigraphic units corresponding to alternating (relatively) wet and dry climate phases, with the development of incipient soils during the Upper Pleniglacial. Indeed, the Nussloch Upper Pleniglacial

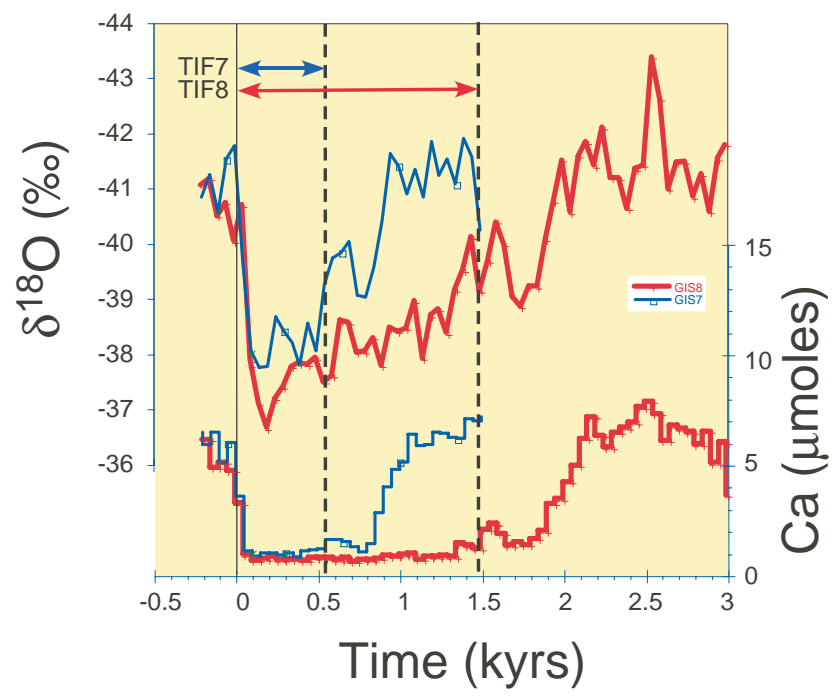

Fig. 9. Temporal evolution of the Dansgaard-Oeschger (DO) events 8 and 7 as expressed in GRIP ice-core data: $\delta^{18} \mathrm{O}(\%$, top) and calcium $(\mathrm{Ca}$, representing dust) concentration $(\mu \mathrm{M}$, bottom) (Johnsen et al., 2001) (from Rousseau et al., 2007 modified). The start of an event (time $=0 \mathrm{kyr}$ ) is given by the beginning of $\delta^{18} \mathrm{O}$ enrichment in the ice core records (vertical black line) (cf. Ganopolski and Rahmstorf, 2001). TIF: time interval favorable for soil development in Europe. We note that the correct denomination of DO interstadials (DOI) is Greenland Interstadials GIS (Rousseau et al., 2006).

sequence consists in an alternation of gleys or oxidized horizons and loess units, described as gley-loess doublets (Rousseau et al., 2002). These doublets are linked to the abrupt climate changes identified in the North Atlantic and Greenland cores: the tundra gleys or oxidized horizons (labeled G and IG on Fig. 7) are associated with Greenland interstadials, and the loess units correspond to Greenland stadials or to Heinrich events (Rousseau et al., 2002, 2007). The Löhner Boden (LB) (Fig. 7), at the base of this high resolution series, was initially interpreted as corresponding to GIS 8 (Antoine et al., 2001; Rousseau et al., 2002, 2007). Its stratigraphic and age allocation was recently questioned (Antoine et al., 2009) as being possibly younger, associated with GIS 7. LB was described as a Bw horizon of a cambisol (Antoine et al., 2001), resulting from a hypothesized pedogenesis yielding different soil horizons. If the GRIP/NGRIP ice-core records are taken as a time reference for the general atmospheric dynamics associated with the Dansgaard-Oeschger (DO) event succession, one can address this key point of the LB time allocation by analyzing the time intervals during which the dust concentration was very low in Greenland. Such periods of low dust concentration in Greenland ice, implying a reduced atmospheric activity in terms of dust cycle (reduced dust emission, transport and deposition) correspond to the maximum of the DO warming and the beginning of the cooling toward stadial conditions, as indicated by the corresponding $\delta^{18} \mathrm{O}$ records. Figure 9 shows the variations of the 


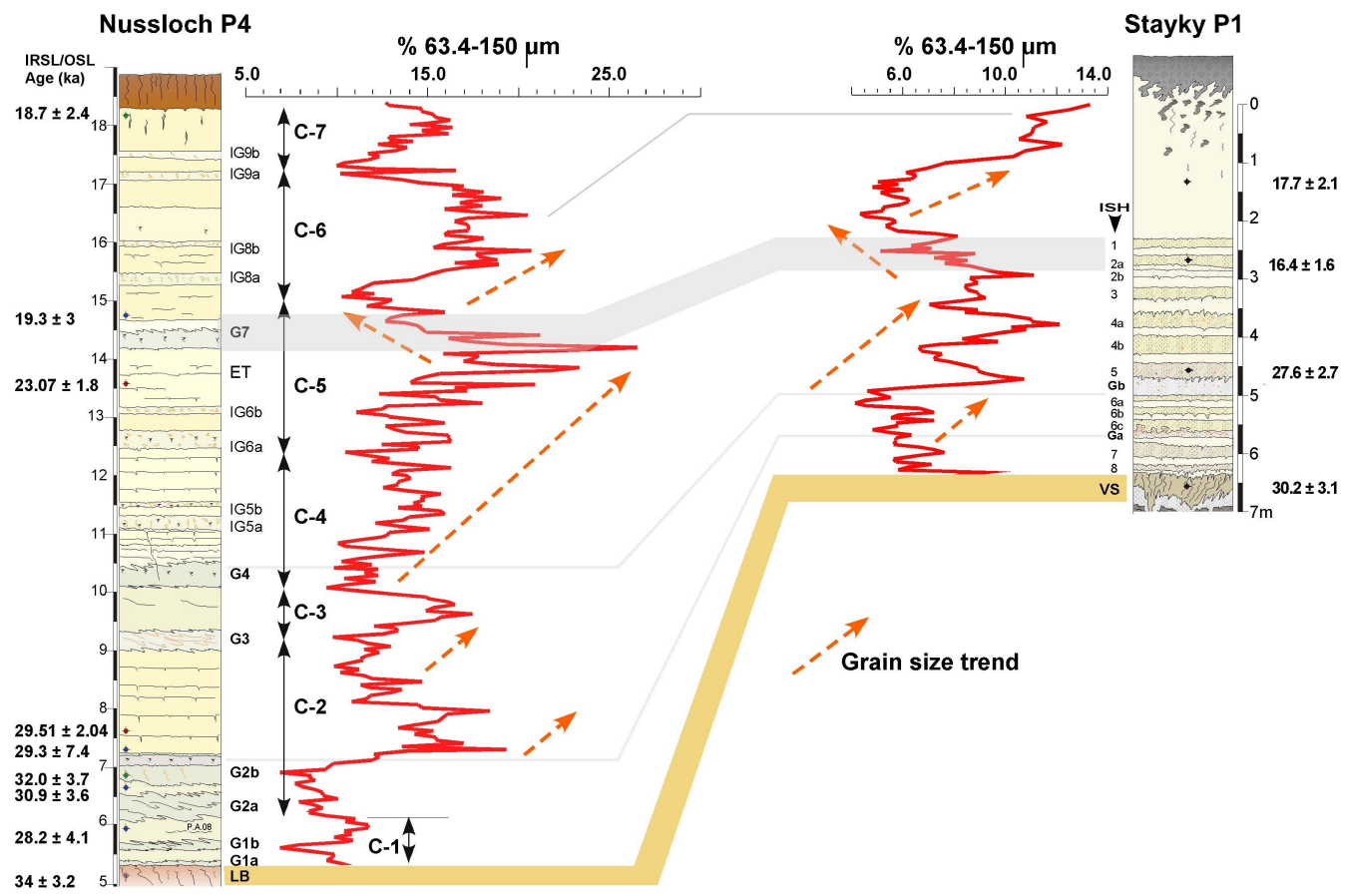

Fig. 10. Comparison of the variation of the coarse grain size fraction (\% 63.4-150 $\mu \mathrm{m})$ in Stayky and Nussloch reference sequence (from Antoine et al., 2009)

$\delta^{18} \mathrm{O}$ and dust concentration in the Greenland ice-cores for GIS 8 and 7. They are plotted by considering the start of the $\delta^{18} \mathrm{O}$ enrichment as time zero of the DO event (cf. Ganopolski and Rahmstorf, 2001). $\delta^{18} \mathrm{O}$ and dust show similar patterns in GIS 8 and 7, except for the duration of the event itself. The change from interstadial to stadial conditions, steep in the dust record, and more gradual in the $\delta^{18} \mathrm{O}$ one, occurs after about 500 years in GIS 7, and after about 1500 years in GIS 8. Describing the different factors of soil formation, Jenny (1994) estimates that the dust deposited by a violent dust storm would need about 1000 years of appropriate conditions to develop into soils. He considers that, while not being totally mature, such a deposit would acquire profile characteristics recognizable in the field. Birkeland (1984) lately supported such investigation. Therefore, GIS 8 appears as the best candidate to correlate with the Löhner Boden, supporting our previous interpretation (Rousseau et al., 2002, 2007). In the Stayky sequence, G8 will correspond to the stratigraphic equivalent of LB, the Vitachev pedocomplex.

The GSI evolution in the Nussloch and Stayky sequences, separated by some $1800 \mathrm{~km}$, is very similar (Fig. 7). At Stayky, GSI shows an increasing trend, with low values in the Vytachiv soil complex, at the base of the profile, and higher values in the upper part of the Bug loess. A maximum value is reached at about $1.5 \mathrm{~m}$ below the top of the Bug unit. A succession of four cycles can be seen, each cycle characterized by an abrupt increase of GSI, followed by a slow decrease. Due to differences in sedimentation rates, only one cycle is visible at the base of the Stayky sequence, instead of two at Nussloch. The loess-gley/pedogenic horizon alternation and the associated grain size index variations are probably mainly the result of changes in the conditions at the source areas and in the strength of the eolian activity.

Another characteristic shared by the two sequences are the increased moisture conditions during the soil formation. At Stayky this is proved by the development of arboreal vegetation, indicated by pollen analysis. No pollen has been preserved in the Nussloch sediments, but increased moisture during gley horizon formation is revealed by the presence of specific terrestrial mollusks, especially on top of these units (Moine et al., 2008). Gleys and pseudogleys form where water is held temporarily above a slowly permeable or impervious horizon. At Nussloch, the presence of a barrier to drainage, probably a permafrost, hampered water percolation, so that perched water remained within the sediment, giving to the sediment the characteristic color.

Taking into account the available dates and the stratigraphic similarities, a correlation between the two sequences can be proposed that Fig. 10 is illustrating when showing the variation of coarse fraction of the grain size. Thus, we propose that the weakly developed soil horizons evidenced in Stayky are the stratigraphic equivalent of the western tundra gleys and characterize the eastern expression of the Greenland interstadials, while the loess units correspond, as those from Nussloch, to Greenland stadials.

Concerning the Heinrich events at Stayky, the GSI shows a first strong increase at a time corresponding to $\mathrm{H} 3$, and reaches its maximum value at a stratigraphic level 
synchronous with H2. Thus, both loess sequences appear to record the climate effect of $\mathrm{H} 3$ and $\mathrm{H} 2$ in the same way, as peaks of the GSI. There is also a remarkable difference: eolian laminations are observed in the corresponding units at Nussloch, but not at Stayky. One of the conditions required for laminations to form is availability of sand in the main efficient wind direction (Antoine et al., 2009; and references therein). While sand is largely available east of Stayky, little is found at the loess site, which means that the main efficient winds are not eastern (but rather western or northwestern, as explained above (Fig. 5). This explains the lack of laminations, as well as the high clay content. Modeling studies on the North Atlantic millennial timescale variations (Claussen et al., 2003; Hostetler et al., 1999), show increased temperatures and precipitation during the Greenland interstadials compared to stadials over most of the Eurasia, especially north of $45^{\circ} \mathrm{N}$. This is in agreement with the interpretation of the stratigraphy, grain-size and pollen analyses at Stayky, and with the correlation with western Europe sequences that we propose, supporting the previous interpretation of Haesaerts et al. (2003), based on soil stratigraphies.

\section{Conclusions}

The new sequence investigated at the Stayky loess site in the Ukraine shows a record of rapid climatic changes in eastern Europe during the last glacial period. As in all the other European sequences analyzed, this record is particularly detailed for the Upper Pleniglacial (ca. 38-17 ka), characterized by particularly high sedimentation rates. Similar to the western European deposits, the stratigraphy shows an alternation of loess units and incipient soil horizons, an expression of the climate changes induced by the North Atlantic stadialinterstadial variations. We propose a fine correlation between the loess profile from Stayky and that from Nussloch (Germany), which is a reference for the western European sequences. This correlation has been established by associating the observed embryonic soils with western European tundra gleys, taking into account the available dates. Similar to the situation at Nussloch, two maxima of the grains size index, computed as the ratio between coarse and fine grainsize fractions, appear to be contemporaneous with Heinrich events 3 and 2. Thus, we have shown that the climate impact of the North Atlantic abrupt changes during the Last Glacial has extended at least to Stayky, and that eastern European loess deposits have recorded these changes in a generally similar way as the western ones, with differences mainly due to a more continental climate.

Future investigations at other European loess sites should provide insight into the specific ways of recording the North Atlantic variability in different parts of the continent as a result of the combination of the large-scale climate influences with regional environmental conditions. Also, the Stayky profile could be used as a reference for further comparison between European and Asian sequences.

Acknowledgements. We thank Henrik Blanchard for performing the IRSL measurements on a Daybreak 1150 TL/OSL system and Manfred Fischer for preparing the IRSL samples. We would like to thank editor Luke Skinner and two anonymous reviewers for useful comments, which improved the manuscript. This study started via the project EOLE, within the frame of the ECLIPSE program funded by the French INSU, and was completed under the ACTES project funded by the French ANR Blanc program (BLAN08-3_309053). This is LDEO contribution \#7444 and LSCE contribution \#4469.

Edited by: L. Skinner

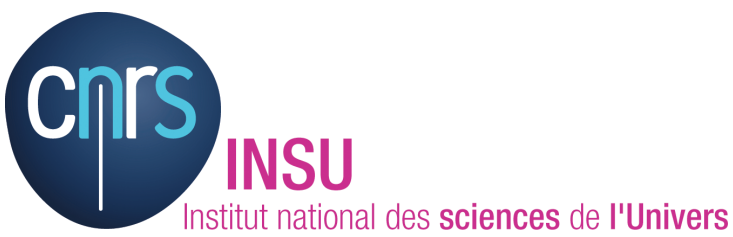

The publication of this article is financed by CNRS-INSU.

\section{References}

Adolphs, U. and Wendler, G.: A Pilot-Study on the Interactions between katabatic winds and polynyas at the Adelie Coast, Eastern Antarctica, Antarctic Science, 7, 307-314, 1995.

Antoine, P., Rousseau, D. D., Lautridou, J. P., and Hatté, C.: Last interglacial-glacial climatic cycle in loess-paleosol successions of north-western France, Boreas, 28, 551-563, 1999.

Antoine, P., Rousseau, D. D., Zoeller, L., Lang, A., Munaut, A. V., Hatté, C., and Fontugne, M.: High-resolution record of the last interglacial-glacial cycle in the loess palaeosol sequences of Nussloch (Rhine Valley-Germany), Quatern. Int., 76/77, 211-229, 2001.

Antoine, P., Rousseau, D. D., Moine, O., Kunesch, S., Hatté, C., Lang, A., Tissoux, H., and Zoeller, L.: Rapid and cyclic aeolian deposition during the Last Glacial in European loess: a high-resolution record from Nussloch, Germany, Quaternary Sci. Rev., 28, 2955-2973, doi:10.1016/j.quascirev.2009.08.001, 2009.

Berger, G. W.: Thermoluminescence dating of the Pleistocene Old Crow tephra and adjacent loess, near Fairbanks, Alaska, Can. J. Earth Sci., 24, 1975-1984, 1987.

Birkeland, P. W.: Soils and Geomorphology, Oxford University Press, New York - Oxford, 372 pp., 1984.

Bond, G. C. and Lotti, R.: Iceberg discharges into the North Atlantic on millennial time scales during the last glaciation, Science, 267, 1005-1010, 1995.

Buggle, B., Hambach, U., Glaser, B., Gerasimenko, N., Markovic, S., Glaser, I., and Zoeller, L.: Stratigraphy, and spatial and temporal paleoclimatic trends in Southeastern/Eastern European loess-paleosol sequences, Quatern. Int., 196, 86-106, doi:10.1016/j.quaint.2008.07.013, 2009. 
Claussen, M., Ganopolski, A., Brovkin, V., Gerstengarbe, F. W., and Werner, P.: Simulated global-scale response of the climate system to Dansgaard/Oeschger and Heinrich events, Clim. Dynam., 21, 361-370, 2003.

Duce, R. A.: Sources, Distributions, and fluxes of mineral aerosols and rheir Relationship to climate, in: Aerosol Forcing of Climate, edited by: Charlson, R. J. and Heintzenberg, J., Wiley and Sons Ltd, Londres, 43-72, 1995.

Frechen, M., Oches, E. A., and Kohfeld, K. E.: Loess in Europemass accumulation rates during the Last Glacial Period, Quaternary Sci. Rev., 22, 1835-1857, 2003.

Ganopolski, A. and Rahmstorf, S.: Rapid changes of glacial climate simulated in a coupled climate model, Nature, 409, 153$158,2001$.

Gerasimenko, N.: Upper Pleistocene loess-palaeosol and vegetational successions in the Middle Dnieper Area, Ukraine, Quatern. Int., 149, 55-66, 2006.

Gerasimenko, N. and Rousseau, D. D.: Stratigraphy and paleoenvironments of the last Pleniglacial in the Kyiv loess region (Ukraine), Quaternaire, 19, 293-307, 2008.

Haesaerts, P., Borziak, I., Chirica, V., Damblon, F., Koulakovska, L., and van der Plicht, J.: The east Carpathian loess record: A reference for the middle and late pleniglacial stratigraphy in central Europe, Quaternaire, 14, 163-188, 2003.

Hatté, C., Fontugne, M., Rousseau, D. D., Antoine, P., Zoeller, L., Tisnérat-Laborde, N., and Bentaleb, I.: $\delta^{13} \mathrm{C}$ variations of loess organic matter as a record of the vegetation response to climatic changes during the Weichselian, Geology, 26, 583-586, 1998.

Hatté, C., Antoine, P., Fontugne, M., Lang, A., Rousseau, D. D., and Zoeller, L.: $\delta^{13} \mathrm{C}$ of loess organic matter as a potential proxy for paleoprecipitation, Quaternary Res., 55, 33-38, 2001.

Hostetler, S. W., Clark, P. U., Bartlein, P. J., Mix, A. C., and Pisias, N. J.: Atmospheric transmission of North Atlantic Heinrich events, J. Geophys. Res., 104, 3947-3952, 1999.

Jenny, H.: Factors of soil formation: A system of quantitative pedology, Dover Publications, New-York, 191 pp., 1994.

Johnsen, S. J., Dahl-Jensen, D., Gundestrup, N., Steffensen, J. P., Clausen, H. B., Miller, H., Masson-Delmotte, V., Sveinbjörnsdottir, A. E., and White, J.: Oxygen isotope and palaeotemperature records from six Greenland ice-core stations: Camp Century, Dye-3, GRIP, GISP2, Renland and NorthGRIP, J. Quaternary Sci., 16, 299-307, 2001.

Kukla, G.: Pleistocene land-sea correlations. 1. Europe, Earth-Sci. Rev., 13, 307-374, 1977.

Kukla, G., Heller, F., Liu, X. M., Xu, T. C., Liu, T. S., and An, Z. S.: Pleistocene climates in China dated by magnetic susceptibility, Geology, 16, 811-814, 1988.

Lang, A., Hatté, C., Rousseau, D. D., Antoine, P., Fontugne, M., Zoeller, L., and Hambach, U.: High-resolution chronologies for loess: comparing $\mathrm{AMS}^{14} \mathrm{C}$ and optical dating results, Quaternary Sci. Rev., 22, 953-959, 2003.

Lautridou, J. P.: Le cycle périglaciaire Pléistocène en Europe $\mathrm{du}$ Nord-Ouest et plus particulièrement en Normandie, Centre Géomorphologie Caen, Université Caen, Caen, 908 pp., 1985.

Lautridou, J. P., Monnier, J. L., Morzadec-Kerfourn, M. T., Sommé, J., and Tuffreau, A.: Les subdivisions du Pléistocène de la France septentrionale stratigraphie, paléogéographie et paléolithique, Projet 73/1/24, Paris-Italy, 148-170, 1983.

Lautridou, J. P., Sommé, J., Heim, J., Maucorps, J., Puisségur, J.
J., Rousseau, D. D., Thévenin, A., and Van Vliet-Lanoé, B.: Corrélations entre sédiments quaternaires continentaux et marins (littoraux et profonds) dans le domaine France septentrionaleManche, Revue Geol. dyn. Géogr. phys., 27(2), 105-112, 1986.

Jin, L., Chen, F. H., Ganopolski, A., and Claussen, M.: Response of East Asian climate to Dansgaard/Oeschger and Heinrich events in a couple model of intermediate complexity, J. Geophys. Res., 112, D06117, doi:10.1029/2006JD007316, 2007.

Mauz, B., Bode, T., Mainz, E., Blanchard, H., Hilger, W., Dikau, R., and Zoeller, L.: The luminescence dating laboratory at the University of Bonn: Equipment and procedures, Ancient TL, 20, 53-61, 2002.

Moine, O., Rousseau, D. D., and Antoine, P.: The impact of Dansgaard-Oeschger cycles on the loessic environment and malacofauna of Nussloch (Germany) during the Upper Weichselian, Quaternary Res., 70, 91-104, doi:10.1016/j.yqres.2008.02.010, 2008.

Pye, K.: The nature, origin and accumulation of loess, Quaternary Sci. Rev., 14, 653-657, 1995.

Rousseau, D. D., Kukla, G., Zoeller, L., and Hradilova, J.: Early Weichselian dust storm layer at Achenheim in Alsace, France, Boreas, 27, 200-207, 1998a.

Rousseau, D. D., Zoeller, L., and Valet, J. P.: Late Pleistocene climatic variations at Achenheim, France, based on a magnetic susceptibility and TL chronology of loess, Quaternary Res., 49, 255-263, 1998b.

Rousseau, D. D., Gerasimenko, N., Matviischina, Z., and Kukla, G.: Late Pleistocene environments of the Central Ukraine, Quaternary Res., 56, 349-356, 2001.

Rousseau, D. D., Antoine, P., Hatté, C., Lang, A., Zoeller, L., Fontugne, M., Ben Othman, D., Luck, J. M., Moine, O., Labonne, M., Bentaleb, I., and Jolly, D.: Abrupt millennial climatic changes from Nussloch (Germany) Upper Weichselian eolian records during the Last Glaciation, Quaternary Sci. Rev., 21, 1577-1582, 2002.

Rousseau, D. D., Kukla, G., and McManus, J.: What is what in the ice and the ocean?, Quaternary Sci. Rev., 25, 2025-2030, 2006.

Rousseau, D. D., Sima, A., Antoine, P., Hatté, C., Lang, A., and Zoeller, L.: Link between European and North Atlantic abrupt climate changes over the last glaciation, Geophys. Res. Lett., 34, L22713, doi:10.1029/2007g1031716, 2007.

Schirmer, W.: Rhein Loess, ice cores and deep sea cores during MIS 2-5, Zeitschrift der Deutschen geologischen Gesellschaft, 151, 309-332, 2000.

Sima, A., Rousseau, D. D., Kageyama, M., Ramstein, G., Schulz, M., Balkanski, Y., Antoine, P., Dulac, F., and Hatté, C.: Imprint of North-Atlantic abrupt climate changes on western European loess deposits as viewed in a dust emission model, Quaternary Sci. Rev., 28, 2851-2866, doi:10.1016/j.quascirev.2009.07.016, 2009.

Smiley, T. L., Bryson, R. A., King, J. E., Kukla, G. J., and Smith, G. I.: Quaternary paleoclimates, in: Quaternary Nonglacial Geology: Conterminous U.S. The Geology of North America, edited by: Morrison, R. B., The Geological Society of America, Boulder, 13-44, 1991.

Svendsen, J. I., Alexanderson, H., Astakhov, V. I., Demidov, I., Dowdeswell, J. A., Funder, S., Gataullin, V., Henriksen, M., Hjort, C., and Houmark-Nielsen, M.: Late Quaternary ice sheet history of northern Eurasia, Quaternary Sci. Rev., 23, 1229- 
1271, 2004.

Tutkovsky, P. A.: Iskopaemye pustyni Severnogo polusharia (Fossil deserts of the Northern Hemisphere), Zemlevedenie, 1-4, 373, 1910.

Veklitch, M. F., Sirenko, N. A., Matviishina, Z. N., Mel'nichuk, I. V., Nagirny, V. N., Perederiy, V. P., Turlo, S. I., Gerasimenko, N. P., and Vozgrin, B. D.: Palaeogeografia Kievskogo Pridneprovya (Palaeogeography of the Kiev-Dnieper Area), Naukova dumka, Kiev, 176 pp., 1984a (in Russian).

Veklitch, M. F., Sirenko, N. A., Volkov, N. G., Shovkoplyas, I. G., Dubnyak, V. A., Korniets, N. L., Lavrushin, Y. A., Matviishina, Z. N., Melnichuk, I. V., Nagirhy, V. N., Peredery, V. I., Solovitsky, V. N., Turlo, S. I., Chugunny, Y. G., Barshchevsky, N. E., Vozgrin, B. D., Gerasimenko, N. P., Gladkikh, M. I., and Kolomiets, G. D.: Quaternary geology of the Dnieper area., International Geological Congress, XXVII session, 64-81, 1984b.
Wallén, C. C.: World Survey of Climatology: Climates of Northern and Western Europe, edited by: Landsberg, H. E., Elsevier Publishing Company, Amsterdam, 253 pp., 1970.

Wintle, A.: Luminescence dating: laboratory procedures and protocols, Radiation Measurements, 27, 769-817, 1997.

Zoeller, L.: New approaches to European loess: a stratigraphic and methodical review of the past décade, Central European Journal Geosciences, 2, 19-31, doi:10.2478/v10085-009-0047-y, 2010. 